\title{
A Study on the Educational Approach of the Second Class Report Card System Based on the Students' Mental Health Level
}

\author{
Zhen Li \\ Shandong Technology and Business University \\ Yantai, China
}

\begin{abstract}
The introduction of the second classroom report card system in national colleges and universities indicates that colleges and universities throughout the country will pay more attention to the work theory of educating people in the second classroom. At present, the second classroom has carried out many activities, such as innovation and entrepreneurship, social practice and so on. However, there are few researches based on the level of college students' mental health. This paper takes this as a starting point to understand the psychological status of contemporary college students through questionnaires, and based on this as the second classroom to better play the role of education, provide path support.
\end{abstract}

Keywords—mental health; second class; approach

\section{INTRODUCTION}

At present, many college students have psychological health problems, which have become an important factor restricting their comprehensive development. As college workers, we must actively take measures to promote students' mental health development. The second class is a popular way for students to participate in activities. We can use this platform to promote students' mental health development.

\section{SECOND ClASS REPORT CARD SYSTEM}

Since 2016, when the Communist Youth League Central Committee and the Ministry of Education jointly issued papers requesting colleges and universities to implement the second classroom report card system, it has been piloted in hundreds of colleges and universities throughout the country, and has achieved good results. The Communist Youth League Central Committee and the Ministry of Education issued a document stating that in the autumn semester of 2018, the "second classroom report card" system will be popularized and implemented for colleges and universities throughout the country, requiring colleges and universities to draw full lessons from the first classroom teaching mechanism and work system to establish a scientific system. Systematic, institutionalized, standardized group work and the second classroom, so that the second classroom can be recorded, evaluated, measured and presented, in-depth mining of the second classroom educational value, generating Scientific and accurate "the second class report card" provides the important basis for the school talented person training appraisal, the student comprehensive quality appraisal, the social unit selects and employs the person. At present, the second classroom includes many activities, such as students' social practice, scientific and technological innovation, and voluntary service and so on, which has become an important platform for colleges and universities to guide students to develop in an all-round way. However, there are few activities based on the mental health level of college students, so educators need to do some research around it.

\section{College Students' Mental Health LeVel ANALYSIS}

In order to fully understand the mental health level of contemporary college students, colleges and universities carry out psychological survey of students during the period of admission, mainly through UPI and SCL-90 to complete .UPI (University Personality Inventory) is the abbreviation of "College students' Personality Health questionnaire". It is a mental health checklist for college students for early detection and treatment of psychological problems. In 1966, it was compiled by a group of psychological counsellors and psychiatrists in Japanese universities. Fan Fumin and others held a national research on the application of UPI. The relative items, screening criteria and implementation process of UP I are systematically revised. SCL-90 symptom Checklist (SCL-90) is one of the most famous mental health test scales in the world, which was introduced into China in the 1980s. It has been widely used in the clinical work of psychiatric department and mental health clinic. The scale is based on the Hopkin's pathology list (HSCL 1973) compiled by Derogatis. It mainly evaluates whether a person has a certain psychological symptom and its severity from the perspectives of feeling, emotion, thinking, consciousness, behavior, life habits, interpersonal relationship, diet and sleep, etc.

\section{A. The Results and Analysis of UPI Survey}

We selected 525 people in Shandong Institute of Business and Technology for analysis, including 523 
effective questionnaires of UPI, the situation is as follows: of 523 people, $67(12.81 \%)$ have poor mental health status, which belongs to the first class of key concern; In addition, 132 people $(25.24 \%)$ were in poor mental health status, belonging to the second class of secondary key concern, and $324(61.95 \%)$ were in good mental health, belonging to three categories of non-key concern, as it shows in "Table I".

TABLE I. THE RESULTS OF UPI SURVEY

\begin{tabular}{|c|l|l|l|l|l|l|l|l|}
\hline & \multicolumn{2}{|c|}{ Class 1 } & \multicolumn{2}{c|}{ Class 2 } & \multicolumn{3}{c|}{ Class 3 } & \multicolumn{2}{c|}{ Total number } \\
\hline Man & 18 & $3.44 \%$ & 50 & $9.56 \%$ & 82 & $15.68 \%$ & 150 & $28.68 \%$ \\
\hline Woman & 49 & $9.37 \%$ & 82 & $15.68 \%$ & 242 & $46.27 \%$ & 373 & $71.32 \%$ \\
\hline Total & 67 & $12.81 \%$ & 132 & $25.24 \%$ & 324 & $61.95 \%$ & 523 & $100.00 \%$ \\
\hline
\end{tabular}

1) Distribution of persons with problem groups by unit: A class refers to a total score of more than 25 points (including 25 points), that is to say, the number of positive factors has reached 25 , or the answer to the person who has thought of suicide, can also be the person who thinks he has a psychological problem. In this survey, the total number of people who belong to the first class problem is 67, accounting for $12.81 \%$ of the total subjects. Among them, the number of male students is 18 , accounting for $3.44 \%$ of the male students, and the number of female students is 49 , accounting for $9.37 \%$ of the female students.
2) Distribution of personnel with three typical positive factors: Of these 56 positive factors, the more common and typical factors are suicide, insomnia and inferiority complex. Among them, the insomnia factor reached 29 people, accounting for 5.54 of the total number, and the inferiority factor reached 52 people, accounting for $9.94 \%$ of the total number of people most worthy of attention is the number of people who answered the idea of suicide reached 15 , accounting for 2.87 percent of the total number. The top 10 questions that affect students' mental health are as it shows in "Table II":

TABle II. The Top 10 Questions That Affect Students’ Mental Health

\begin{tabular}{|l|l|l|l|}
\hline $\begin{array}{c}\text { Serial } \\
\text { number }\end{array}$ & \multicolumn{1}{|c|}{ Title } & \multicolumn{1}{|c|}{$\begin{array}{c}\text { Number of } \\
\text { people }\end{array}$} & \multicolumn{1}{c|}{ Percentage } \\
\hline 1 & 22. Love to worry about & 199 & $38.05 \%$ \\
\hline 2 & 58. Care about other people's sight. & 198 & $37.86 \%$ \\
\hline 3 & 57. Always pay attention to the people around you & 174 & $33.27 \%$ \\
\hline 4 & 53. Care about dirt. & 170 & $32.50 \%$ \\
\hline 5 & 28. Lack of endurance & 163 & $31.17 \%$ \\
\hline 6 & 29. Lack of determination & 163 & $31.17 \%$ \\
\hline 7 & 14. Thought is not concentrated & 158 & $30.21 \%$ \\
\hline 8 & 9. Worry too much about the future & 153 & $29.25 \%$ \\
\hline 9 & 27. Memory loss & 150 & $28.68 \%$ \\
\hline 10 & 38. Lack of self-confidence & 150 & $28.68 \%$ \\
\hline
\end{tabular}

\section{B. The Results and Analysis of SCL-90 Survey}

1) Overall results: The results of 521 valid questionnaires showed that 135 persons had psychological distress, accounting for $25.91 \%$ of the total participants, 33 of them had moderate and severe distress, and $6.33 \%$ of the total participants, as it shows in "Table III". According to the results of national norm, the total score of (1-5 grades) is more than 160 points, or the number of positive items is more than 43 items, or any factor score is more than 2 points, you can consider screening positive, need further examination. It is generally stipulated that any factor score or total mean score $\geq 3$ is positive, indicating that there are mental health problems of moderate degree or above.

TABLE III. OVERALL RESULTS

\begin{tabular}{|c|l|l|}
\hline & \multicolumn{1}{|c|}{ Positive symptom person } & $\begin{array}{c}\text { Persons with moderate and severe } \\
\text { symptoms }\end{array}$ \\
\hline number of people & 135.00 & 33.00 \\
\hline Percentage of total assessment & $25.91 \%$ & $6.33 \%$ \\
\hline
\end{tabular}




\section{2) Summary of overall screening results}

TABLE IV. SUMMARY OF OVERALL SCREENING RESULTS

\begin{tabular}{|c|c|c|c|c|c|c|}
\hline \multirow[b]{2}{*}{$\mathrm{N}=\mathbf{5 2 1 . 0 0}$} & \multicolumn{2}{|c|}{ Factor score $<3$} & \multicolumn{2}{|c|}{$\mathbf{4}<$ Factor score $\geq 3$} & \multicolumn{2}{|c|}{ Factor score $\geq 4$} \\
\hline & $\begin{array}{c}\text { Number of } \\
\text { people }\end{array}$ & Percentage & $\begin{array}{c}\text { Number of } \\
\text { people }\end{array}$ & Percentage & $\begin{array}{c}\text { Number of } \\
\text { people }\end{array}$ & Percentage \\
\hline Hostile & 509 & $97.70 \%$ & 11 & $2.11 \%$ & 1 & $0.19 \%$ \\
\hline Anxious & 512 & $98.27 \%$ & 9 & $1.73 \%$ & 0 & $0.00 \%$ \\
\hline Psychosis & 517 & $99.23 \%$ & 4 & $0.77 \%$ & 0 & $0.00 \%$ \\
\hline Terrifying & 515 & $98.85 \%$ & 6 & $1.15 \%$ & 0 & $0.00 \%$ \\
\hline Bigoted & 514 & $98.66 \%$ & 7 & $1.34 \%$ & 0 & $0.00 \%$ \\
\hline Other & 521 & $100.00 \%$ & 0 & $0.00 \%$ & 0 & $0.00 \%$ \\
\hline $\begin{array}{l}\text { Obsessive } \\
\text { symptoms }\end{array}$ & 503 & $96.55 \%$ & 18 & $3.45 \%$ & 0 & $0.00 \%$ \\
\hline Somatization & 518 & $99.42 \%$ & 2 & $0.38 \%$ & 1 & $0.19 \%$ \\
\hline $\begin{array}{l}\text { Interpersonal } \\
\text { sensitivity }\end{array}$ & 507 & $97.31 \%$ & 13 & $2.50 \%$ & 1 & $0.19 \%$ \\
\hline Depressed & 516 & $99.04 \%$ & 5 & $0.96 \%$ & 0 & $0.00 \%$ \\
\hline Total mean score & 518 & $99.42 \%$ & 3 & $0.58 \%$ & 0 & $0.00 \%$ \\
\hline
\end{tabular}

a. factor score $<3$ is mild symptom, $4<$ factor score $\geq 3$ is moderate symptom, factor score $\geq 4$ is severe symptom

At the end of the day, we also concluded that the top 10 symptoms are as it shows in "Table V":

TABLE V. THE TOP 10 SYMPTOMS

\begin{tabular}{|c|c|c|c|c|}
\hline $\begin{array}{c}\text { Order } \\
\text { numbe } \\
\mathbf{r}\end{array}$ & Title number & Title & $\begin{array}{c}\text { Number of } \\
\text { people }\end{array}$ & Percentage \\
\hline 1 & 10 & 10. Worry about the neatness and decency of your clothes & 185 & $35.51 \%$ \\
\hline 2 & 9 & 9. Big forgetfulness & 130 & $24.95 \%$ \\
\hline 3 & 46 & 46. Difficulty in making a decision & 123 & $23.61 \%$ \\
\hline 4 & 61 & $\begin{array}{l}\text { 61. Feel uncomfortable when others look at you or talk about } \\
\text { you }\end{array}$ & 121 & $23.22 \%$ \\
\hline 5 & 86 & 86. Feel like finishing things quickly. & 119 & $22.84 \%$ \\
\hline 6 & 11 & 11. Easily vexed and excited & 110 & $21.11 \%$ \\
\hline 7 & 60 & 60. Eat too much & 99 & $19.00 \%$ \\
\hline 8 & 21 & $\begin{array}{l}\text { 21. Feel shy and uneasy when you get along with the opposite } \\
\text { sex. }\end{array}$ & 97 & $18.62 \%$ \\
\hline 9 & 55 & 55. Can't concentrate. & 96 & $18.43 \%$ \\
\hline 10 & 34 & 34. Feelings are vulnerable. & 94 & $18.04 \%$ \\
\hline
\end{tabular}

\section{THE SECOND CLASSROOM REPORT CARD SYSTEM EDUCATES THE WAY}

From the results of the investigation, we can see that the psychological health of contemporary college students is worth worrying. From the results of UPI, we can see that the psychological problems of college students are serious: suicide, insomnia, inferiority complex. From the results of SCL-90, we can see that as many as 1/4 students have certain psychological problems. In addition to the results of the UPI survey, many students have problems in the aspects of choice, interpersonal relations, time management and emotional management. This requires us to design the second classroom activities as a starting point, according to the actual situation of students to design activities, and to ensure the smooth development of the activities.

\section{A. Attaching Importance to the Life Education of Students}

The number of students who had suicidal thoughts from the psychological census accounted for nearly 3 percent, a frightening number. With the development of high-tech, the space distance between people has narrowed, but the actual psychological distance is even farther. This creates a sense of emptiness and loneliness in the hearts of children, as well as growing psychological problems. Moreover, in recent years, because of problems of lovelorn, employment and other problems, people who have committed suicide have frequently appeared. Moreover, it has been studied that students who have had suicidal thoughts are very likely to commit suicide again. The reason is that teenagers do not understand the original meaning of life. They do not understand life, nor do they understand death. Human life is only once, in order to avoid juvenile suicide Or the occurrence of things that hurt others, strengthen the frustration education and mental health education of students, guide students to establish correct outlook on life and values, treat difficulties and setbacks with a positive and optimistic attitude, grow up healthily, and live happily, Be a person who cherishes life, loves life and strives to realize his own value. Therefore, it is necessary to enable children to correctly understand the characteristics of death and the 
significance of life through curriculum guidance, forum communication, quality development, etc., which is an indispensable and important course in the process of teenagers' growth. It is also an important factor to be considered in the second classroom setup activity.

\section{B. Enhancing Students' Self-confidence}

In psychology, inferiority and self-confidence is a pair of antonyms. Inferiority is a state of mind, distrust of oneself and a negative state. It often shows that it does not like to communicate with others, especially with strangers, and is always worried that it is inferior to others; that it does not dare to express its opinions in public, that it is afraid of being laughed at when it is wrong, that it has no backbone, that it is indecisive, Always doubt that his ability is not enough and so on. All these are caused by lack of confidence. Therefore, as educators in colleges and universities, we should carry out a series of activities around this theme, encourage students to study constantly, participate in social activities as much as possible, and enrich their own social experience. Promotion of students Self-confidence, encourage students to say, dare to do, dare to face life. In carrying out their work, special encouragement should be given to those who are usually unwilling to participate in collective activities, which are unwilling to speak in public, who are unwilling to express themselves and, if necessary, can have individual counselling; this can also enable the second classroom activities to play a greater role. In particular, the school requires that each student must complete 12 second class credits while in school, and is unwilling to participate in activities. Students who are difficult to obtain credit generally have some psychological problems to pay attention to. In this way, we set up activity skills to promote students' second class around the students' psychological problems. Credit can also help them solve their own psychological problems, with twice the result with half the effort.

\section{Strengthening Students' Self-management Ability}

Emotion management is a process in which individuals or groups control and regulate their emotions. Emotion management is the process of individual or group to control and regulate emotions. Emotion education is the education of the theory and skills of emotion management for college students. Emotion management and emotion education of college students is the inevitable of the education concept "based on the comprehensive development of students". To improve the ability of emotional management: 1 . Through the course of "emotional management", improve the students' ability of self-emotional awareness. 2. Through various forms of workshops, students should adopt corresponding emotional guidance methods according to different stages of school development, such as adaptive guidance in the freshman year and career development guidance in the junior year to improve students' emotional adaptation ability. 3. To set up peer lecture hall, peer counseling studio to play the role of passing and helping students and to establish a reasonable way of emotional catharsis. 4. The emotional education needs to be carried out both in and out of class, to introduce emotional management into the students' living environment, and to form a good atmosphere of emotional education. Time management is the core of self-management. It refers to a series of control work to improve the utilization and efficiency of time under the same time consumption. Because of everyone's place in social production, it is different and a kind of inherent management quality that endows oneself. Time management is not only a skill that college students must master, but also a basic factor of college life success. However, many college students do not master the skills of time management, which has become an important factor affecting the development of mental health of many people. This can be achieved through: 1. Carry out college career planning competition to enable more students to actively participate in their academic development. 2. Set up special courses to improve college students' time management skills and conduct lectures on an independent topic, teaching the theory and practical application of time management. The main task of the time management training course is to provide students with a clear understanding of their time use and let them know how to reduce or eliminate waste of time. 3. Guide students to make feasible plans according to the semester, month, week and day, and learn to deal with life priorities.

\section{Helping Students Learn to Deal with Interpersonal Relationships}

Through the investigation, it is found that interpersonal relationship is one of the important factors affecting the mental health of college students. The interpersonal relationship of college students mainly includes the relationships between college students and the social members, groups and strata inside and outside the university, which is the basis of college students' interpersonal communication. Specifically, its basic composition includes dormitory membership relationship, class and classmate relationship, teacher-student relationship, family member relationship, lover relationship, personal and class relationship, and so on. College students often have fights, cold wars, suicides and so on because of their classmates and romantic relationships. Through special courses, lectures to teach basic theoretical knowledge, through quality development, for the sake of others and other activities Promote students' communication, help students learn to improve their ability to meet the needs of others through selfgrowth, including sincere praise, sincere smile and sincere care, improve self-efficacy. At the same time, be sure to avoid accusations, complaints, and criticisms that others don't need while actively satisfying other people's needs. So, no matter what happens in your daily contact, you have to think about others, think about how you can get better results, think twice and say, think before you act, and you'll avoid more criticism, and complaints. Interpersonal relationships will also gradually improve.

\section{E. Guiding Students to Master Self-regulation Methods}

A student's lack of self-regulation can lead to irritation, excitement, injury and even insomnia. Many students do not live independently in high school and rely too much on their parents, so they lack the ability to deal with problems correctly. This requires colleges and universities to set up the second classroom activities in order to promote students' 
sense of achievement and self-evaluation as the starting point, through active outdoor sports, self-confidence and positive hinting and other methods to improve students' selfregulation ability. In a word, students' self-regulation ability is affected by the first few factors, so we say that the mental health level of college students is a systematic organic. In order to promote the improvement of students' mental health level, several important factors must be promoted.

\section{CONCLUSION}

Through investigation, it is found that students' psychological problems are an organic entity, so long as the main problems are solved, some minor problems can be solved easily. This requires the vast number of educators to combine the actual situation of students, actively set up courses or activities to meet the students' psychological health growth in the second classroom, and ultimately promote students to have psychological growth and all-round development.

\section{REFERENCES}

[1] Zhao Hualong, Shi Yanling.On the inferiority complex and selfregulation of College students[J].Journal of Shandong Youth Management Cadre College, 1999, (10).

[2] Tian Caifen. A brief Analysis of the Psychological problems and the realization of Mental Health of Contemporary College students [J]. Reform and Development 2001 (08).

[3] Xu Roulan. On College students' emotion Management and emotional Education [J]. Journal of Chengdu University of Technology (Social Sciences Edition), 2003, (12).

[4] Wu Yingfeng. Present situation and Countermeasures of College students' time Management [J]. Talent and Education 2007 (04). 